\title{
Experimental study of shear deformation of the medium formed by the massif of ribbed grains
}

\author{
S.V. Mykulyak, V.O. Polyakovskyi, S.I. Skurativskyi, 2021 \\ S.I. Subbotin Institute of Geophysics of the National Academy of Sciences of Ukraine, \\ Kyiv, Ukraine
}

Received 31 September 2020

\begin{abstract}
The approach to the study of the seismically active zone as an open system that is in a state of self-organized criticality is becoming increasingly used in modern research. The models used in this approach should reflect the most characteristic features of such media: discreteness, nonequilibrium, nonlinear and nonlocal nature of interactions. In this paper, the medium is modeled by a granular massif with ribbed grains. Three different massifs are used in the research. Within one massif, all grains are identical, while grains from different massifs differ in shape (cubic or irregular ribbed) and characteristic size.

A number of experiments of shear deformation of such granular massifs were carried out in order to study the influence of the shape and size of grains on the statistical characteristics of the process. The influence of the stress state on the deformation properties of these media was also studied. The experiments proved the qualitative similarity of the behavior of different granular media. Obtained experimentally force jumps, representing the reaction of the granular medium to shear deformation, obey the distributions in the form of power dependencies. However, the magnitudes of the forces arising in the massifs depend on the grain shape and size as well as the stress state in the massifs. The experiments with shear deformation of the granular media under the external action of small impulse stresses have shown that such action causes a smoother, devoid of sharp jumps, deformation. External perturbations shift the distribution of the force jumps towards smaller values, leaving their exponents unchanged.

The analysis of experimental results using nonadditive statistical mechanics confirmed the presence of long-range correlations in the massif of ribbed granules during its shear deformation.
\end{abstract} index.

Key words: granular medium, shear deformation, power statistical distribution, Tsallis

Introduction. One of the most important properties of the lithosphere is discreteness observed in a wide range of scales: from grains in rocks of millimeter size to the largest structural elements of the Earth's crust - tectonic plates up to thousands of kilometers [Alexeevskaya et al., 1977; Sadovskiy et al., 1982, 1987]. The discrete structure of geomedia determines their special dynamic behavior, different from the behavior of homogeneous media [Sadovskiy et al., 1987; Nikolaevskiy, 1996; Kocharyan, Spivak, 2003]. A striking example of such special behavior is the irregular release of energy in the form of earth- quakes in seismically active zones under their loading due to the regular displacement of tectonic plates [Sadovskiy et al., 1987; Sadovskiy, 1989; Keilis-Borok, Soloviev, 2003; Meade, Hager, 2005]. It is known that the media in seismically active areas are significantly fragmented by numerous faults and cracks [Ben-Zion, Sammis, 2003; Billi, Storti, 2004; Meade, Hager, 2005; McCaffrey, 2005; Loveless, Meade, 2011].

In a number of works it was found that the shear deformation of such discrete media as granular ones is statistically similar to seismic processes in natural media. In particular, the 
experiments [Behringer et al., 1999; Howell et al., 1999; Hayman et al., 2011; Geller et al., 2015; Mykulyak et al., 2019b] and the simulations [Zhao et al., 2006; Indraratna et al., 2014; Mykulyak et al., 2019a] have shown that the displacement of granular media occurs intermittently and is accompanied by the radiation of stochastic acoustic disturbances. It turned out, these disturbances obey the statistical laws inherent in earthquakes, namely Gutenberg Richter's law, Omori's law and also the universal law for distribution of interevent times between avalanches [Geller et al., 2015; Lherminier et al., 2019; Mykulyak et al., 2019b; Kumar et al., 2020].

The authors of [Meade, Hager, 2005; Loveless, Meade, 2011; Meroz, Meade, 2017] studied in detail the movement of tectonic structural elements in California, in the area between two tectonic plates: the Pacific and the North American. This area is divided by a network of faults into a large number of tectonic elements, which as a result of the movement of tectonic plates are also involved in the movement. These studies have shown that the behavior of this region is similar to the shear deformation of the granular medium.

In our previous paper [Mykulyak et al., 2019b] we studied the statistical properties of shear deformation of granular medium experimentally. Since among the fragments of natural rock the mainly ribbed-shaped pieces are common, the cubic grains as structural elements for the massif were chosen. We found out that deformation process is intermittent and accompanied by the radiation of acoustic perturbation obeying the Gutenberg Richter law and the generalized Omori law for temporal decay of aftershocks. We also investigated the effect of small perturbations on shear deformation. The experiments have shown that acting on the medium with small perturbations when the force of tension of a certain threshold value can be achieved, it is possible to attain smoother deformation.

Continuing the research [Mykulyak et al., 2019b], we investigate the influence of grain shape and size on the statistical properties of the shear process. Here we consider two types of grains: cubic grains and grains formed by crushed stone with an irregular but ribbed shape. We study the effect of compression on the statistical characteristics of grain massifs of these two types, as well as the effect of small perturbations.

Experimental installation for the study of shear deformation of ribbed grains massif. The study of shear deformation process of granular media is carried out using the experimental installation (Fig. 1,a) developed in [Mykulyak et al., 2019b; Mykulyak, 2019]. Its main element is the box consisting of two parts: the lower fixed and the upper sliding (Fig. 1). Both parts are made from plexiglass. Each box's part has the following internal sizes: the length along shear direction is $0.3 \mathrm{~m}$, the height is $0.07 \mathrm{~m}$, and the width is $0.2 \mathrm{~m}$.

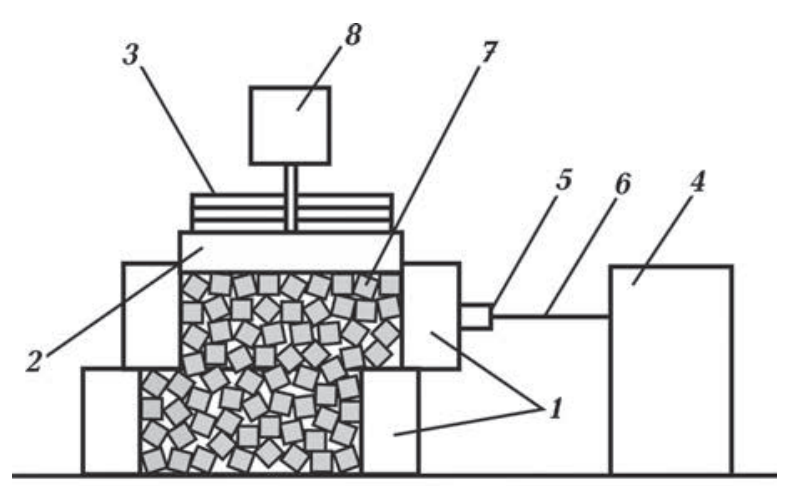

a

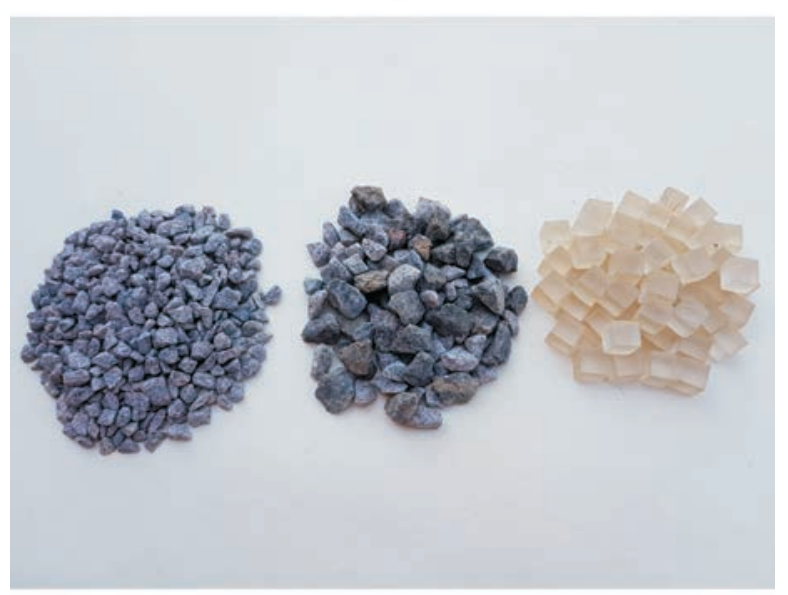

б

Fig. 1. The sketch of experimental setup (a). Designations: 1 - box consisting of two parts, 2 - piston, 3 -load, 4-traction mechanism, 5-force sensor, 6 - rope, 7 - grains, 8 -impulse generator. Three types of grain massifs (from left to right) (b): ribbed grains with sizes $5-7 \mathrm{~mm}$, ribbed grains with sizes $10-15 \mathrm{~mm}$ (crushed stone), cubic grains (plexiglass). 
The front and back wall thickness is $0.1 \mathrm{~m}$. The contact surfaces between the lower and upper boxes were preliminary ground. To provide the horizontal sliding of the upper part , the guide plates were installed on the lower part. In turn, the slider part of the device is equipped with the limiters prohibiting the movement in the vertical direction. The piston (2) that can move freely in a vertical direction is located on the granular massif. The piston weight is $2.75 \mathrm{~kg}$. The movement of the slider block is implemented using a traction mechanism (4). This device consists of a gear motor NMRV 090/040, which is connected to the rope shaft. One end of the rope (6) is attached to the shaft, whereas the other one to the force sensor (5), which is rigidly mounted on the leading edge of the upper box. The force sensor measures the granular massif reaction on the shear deformation.

The study of external perturbations influence on the granular medium shear is carried out for impulse actions. The perturbations are generated by an impulse generator ( 8 ) mounted on the upper surface of the piston (2). Static loading on the granular massif is performed by means of the weights (3) located on the piston. We consider three types of massif (Fig. 1, $b)$. The first one consists of cubic grains $10 \mathrm{~mm}$ in size. The second massif contains the ribbed grains of irregular shape with sizes in the range of $5-7 \mathrm{~mm}$. The third massif differs from the second one by the grain size only, i. e. they are $10-15 \mathrm{~mm}$.

Cubic grains are made of plexiglass and irregular grains are screenings of crushed stone of the corresponding fractions.

The reaction of granular media on shear deformations. In the first series of experiments, we consider the effect of static load on the process of shear deformation of the granular media. In all of them, the displacement of the upper part of the box is carried out at a speed of $10 \mathrm{~cm}$ per minute. The force sensor registers the force response of the medium to the shift. This reaction depending on time is shown in Fig. 2, a for the granular medium with cubic grains pressed by the load $P=30$ $\mathrm{N}$. This dependence is a set of chaotic oscillations. To analyze these oscillations, the jumps
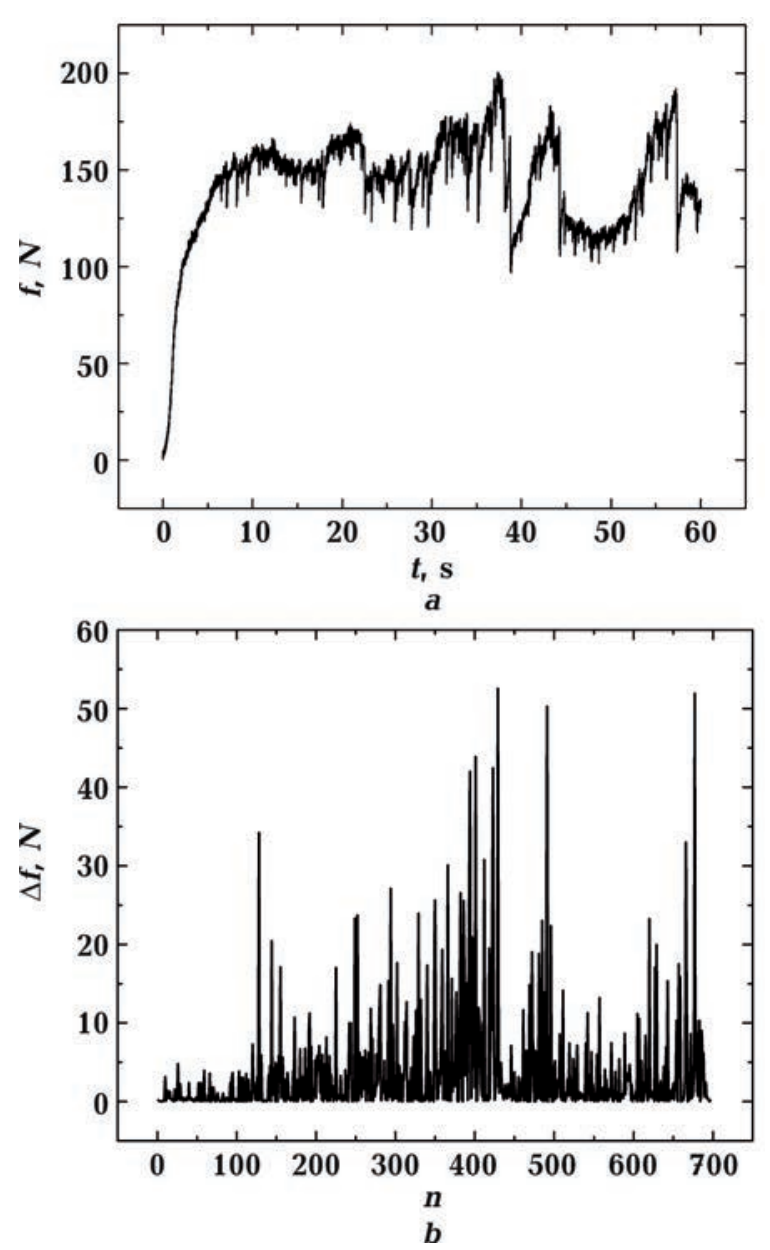

Fig. 2. Temporal dependencies of the traction force $f(t)$ during the shear deformation of cubes massif (a) and the corresponding sequence of the force jumps $\Delta f(t)(b)$.

from the minimum to the maximum values were calculated, and then the distributions of the amplitudes of these jumps were built. Fig. 3 presents the distributions of the force jumps for massif of cubic grains in the absence of load and for two values of loads in log-log coordinates. The figure shows that these distributions are parallel to each other and shift towards greater forces with increasing the loads, which is natural. These distributions are power, and this is typical for processes that take place in a mode of self-organized criticality [Pruessner, 2012].

The distributions of the force jumps for massif of ribbed grains of irregular shape with sizes in the range of $5-7 \mathrm{~mm}$ and in the size range of $10-15 \mathrm{~mm}$ for three loading regimes 


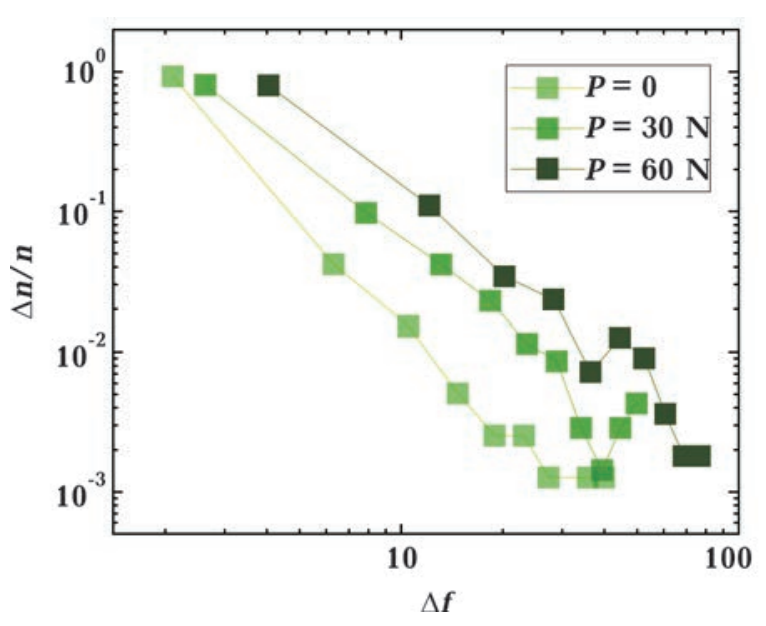

Fig. 3. Distribution of the force jumps $\Delta f$ at three types of static loading. Massif is formed by cubic grains.

are presented in Fig. 4. In both cases the distributions of the force jumps are power functions. The distributions are parallel to each other and shift towards greater forces with increasing the loads, which is natural. In both cases, the distribution of force jumps is almost parallel and there is a shift with increasing compression of the granular medium.

The next series of experiments is devoted to the study of the effect of external impulse perturbations on the shear deformation of granular media. The impulse generator (8) is used to send the signal with the frequency $\omega=$
$=2 \mathrm{~Hz}$ into the medium. The amplitude of the impulse is $f^{m}=44 \mathrm{~N}$, lasted for $\tau=1 \mathrm{~ms}$. The effect of pulsed perturbations on the shear was studied for the massif of cubic granules and for the crushed stone massif with a size of 5-7 mm. The distributions of the force jumps are presented in Fig. 5 for two loads. Here, for comparison, the distributions of force jumps without the influence of pulse perturbations are also given. The analysis of these graphs shows that the action of pulsed perturbations leads to the shift of the distributions towards smaller values and, consequently, to smaller values of jumps, i. e. to a smoother shear deformation.

Analysis of these distributions shows that the perturbations affect the shear deformation, reducing the jumps, and thus making it smoother. This is true for all distributions. This effect is manifested in the shift of distribution functions in the direction of reducing the intensity of force jumps. The slopes of these distributions do not depend on the action of perturbations. This is clearly seen in Fig. 6, $a$, which shows the exponent for different granular media and different deformation conditions. In addition, the graph shows a tendency that the medium with larger granules corresponds to larger $\beta$ values, i. e. in the case of larger granule sizes, the distribution of jumps is more nonuniform. The results of the experi-
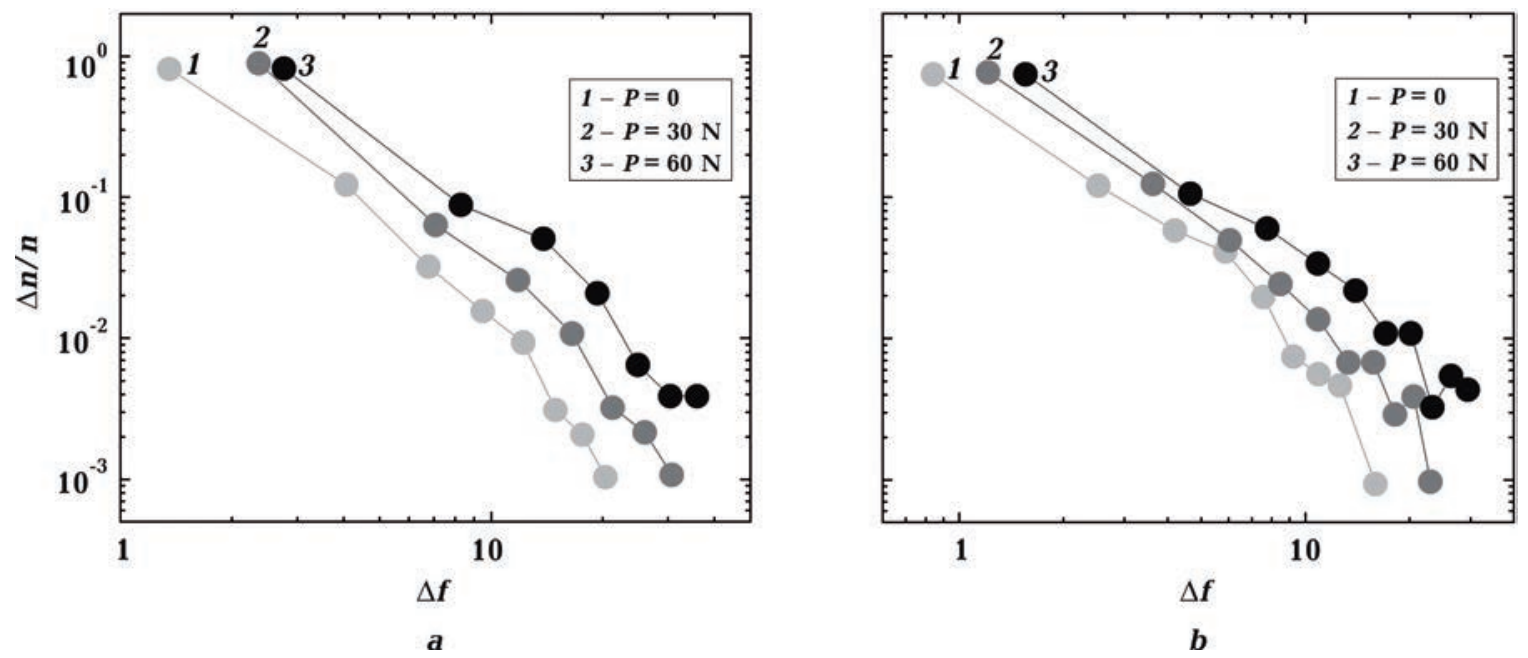

Fig. 4. Distribution of the force jumps $\Delta f$ at three types of static loading. Massif is formed by grains of irregular shape with sizes in the range of $5-7 \mathrm{~mm}(a)$ and in the range of $10-15 \mathrm{~mm}(b)$. 

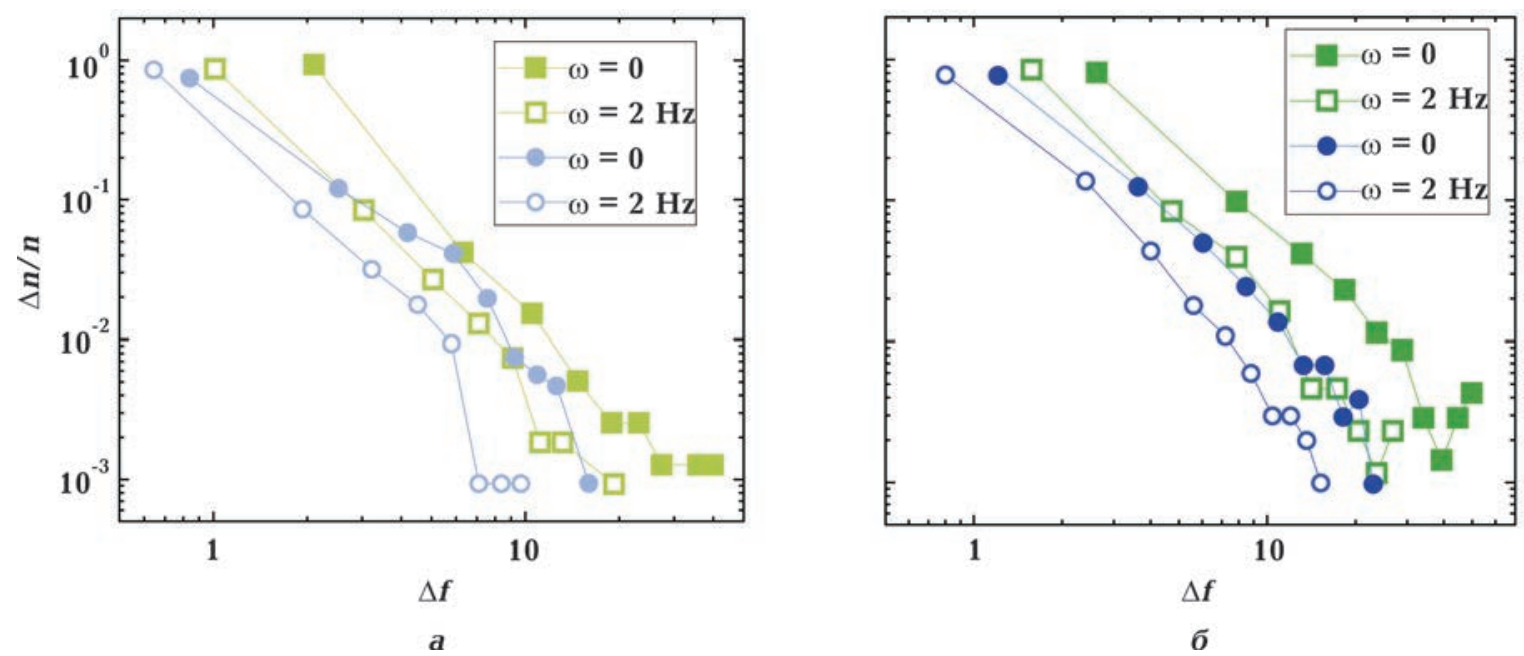

Fig. 5. Distribution of the force jumps $\Delta f$ at loads $P=0(a)$ and $P=30 \mathrm{~N}(b)$ for shear with (empty symbols) and without perturbations (filled symbols). The distribution of the cubic grain massif is denoted by square symbols, and the distribution for the massif formed by irregularly shaped grains with dimensions within 5-7 $\mathrm{mm}$ is indicated by circular symbols.

ments also indicate that the shape and size of the grains affect the deformation properties. The distribution graphs for three discrete arrays shown in Fig. 6, $b$ confirm this. These distributions are similar, but the distributions for arrays with larger irregular granules are shifted toward more intense jumps, and the distributions for an array with cubic granules are further shifted in this direction.

Examination of shear deformation compexity via non-intensive statistical mechanics. The nature of the observed experimental data can be investigated by using the generalized entropy conception [Vallianatos et al., 2012, 2014, 2018; Michas et al., 2013; Vallianatos et al., 2016a, b; Agioutantis et al., 2016; Saltas et al., 2018]. This extension of thermodynamics and statistical physics introduced by Tsallis [2004] deals with the nonergodic systems and leads to the nonextensive thermodynamics and statistical mechanics. Instead of classical entropy, the quantity $S_{T}$ is defined as

Fig. 6. Dependences of exponent $\beta$ on the load $P$ for shear with (empty symbols) and without perturbations (filled symbols) (a). The numbers 1 and 2 correspond to the massif of cubic grains; 3,5 - the massif of $5-7 \mathrm{~mm}$ irregular grains; 4 - the massif of 10 $15 \mathrm{~mm}$ irregular grains. Distributions of the force jumps $\Delta f$ at load $P=60 \mathrm{~N}$ for different media shear $(b)$.
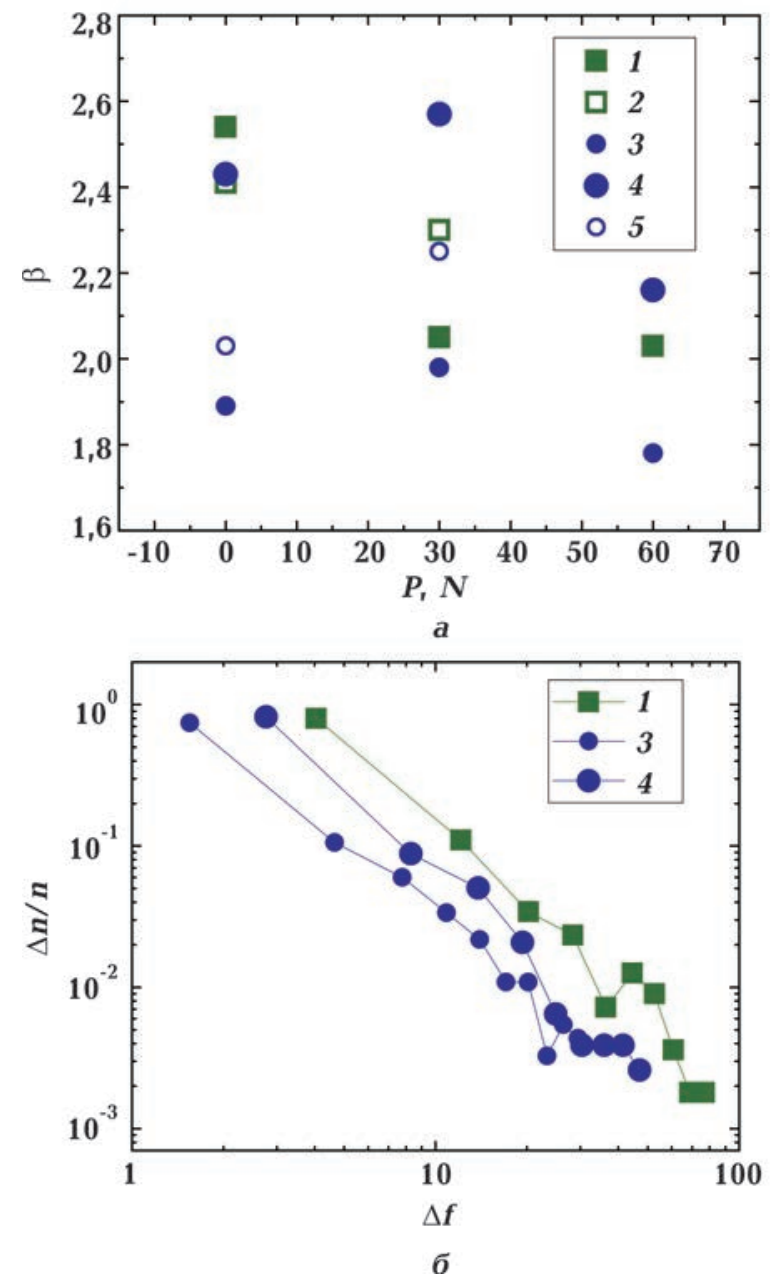

Геофизический журнал № 2, T. 43, 2021 


$$
S_{T}=\frac{1-\sum_{i=1}^{Q} p_{i}^{q}}{q-1}, \quad q \in R,
$$

where $q$ is the Tsallis (or entropy) index, $Q$

$\sum_{i=1} p_{i}=1$. If a system consists of two sta-

tistically independent subsystems $A$ and $B$, Tsallis entropy, $S_{T}$ is defined according to the following expression

$$
\begin{gathered}
S_{T}(A B)=S_{T}(A)+S_{T}(B)+ \\
+\frac{1-q}{k_{B}} S_{T}(A) S_{T}(B),
\end{gathered}
$$

where $k_{B}$ is Boltzmann's constant. The last term reflects the nonadditivity due to longrange interactions in the physical system under consideration. Note that the limit $q \rightarrow 1$ corresponds to the Boltzmann-Gibbs entropy $S_{T} \rightarrow \sum_{i=1}^{Q} p_{i} \ln p_{i}$ and the deviation of $q$ from 1 points to the appearance of long-range correlations. It has been shown that at $q<1$ the physical system behavior depends on rare events, whereas at $q>1$ the frequent events have more weight [Boghosian, 1996].

To estimate the index $q$, the approach proposed in [Ramirez-Reyes et al., 2016] is used. According to this method, the maximum entropy principal on the base of $S_{T}$ is applied. The auxiliary function known as redundancy $R_{T}$ is defined as

$$
R_{T}=1-\frac{S_{T}}{S_{T}^{\max }}
$$

where $S_{T}^{\max }=\frac{1-Q^{1-q}}{q-1}$ is the maximum of the function $S_{T}$, which is reached on the equiprobable microstates $p_{i}=1 / Q$.

In this way, we construct the functions $S_{T}(q)$ and $R_{T}(q)$ using the sequences of force jumps $\Delta f(t)$. Fig. 7 presents these functions built for the experiment with shear deformation of the

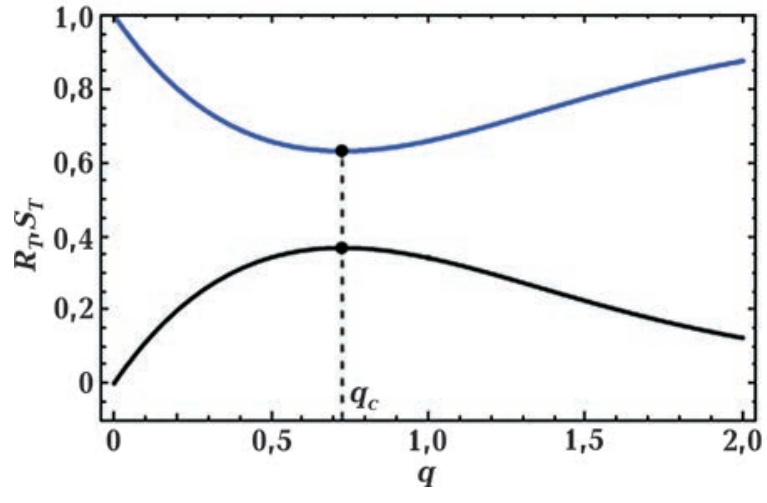

Fig. 7. Determination of entropy index $q$. The functions $R_{T}(q)$ (upper curve) and $S_{T}(q)$ (lower curve). The extremum abscissa is $q=0.73$.

cubic massif without the load. Each of these functions possesses single extremum depicted with the filled circles. The numerical estimation of extremum coordinates gives $q=0.73<$ $<1$. This means that the process described by the distribution of force jumps $\Delta f$ possesses long-range correlations and the system dynamics is defined by the mutual influence of a large number of rare events.

Fig. 8 presents the summary graph for all experiments of the dependence of Tsallis index on the load $P$. The analysis shows that this index does not depend on the value of $P$. However, there is an influence of the shape and size of the grains on Tsallis index. For cubic grains, the index is the largest. It also has a larger value for larger irregular grains.

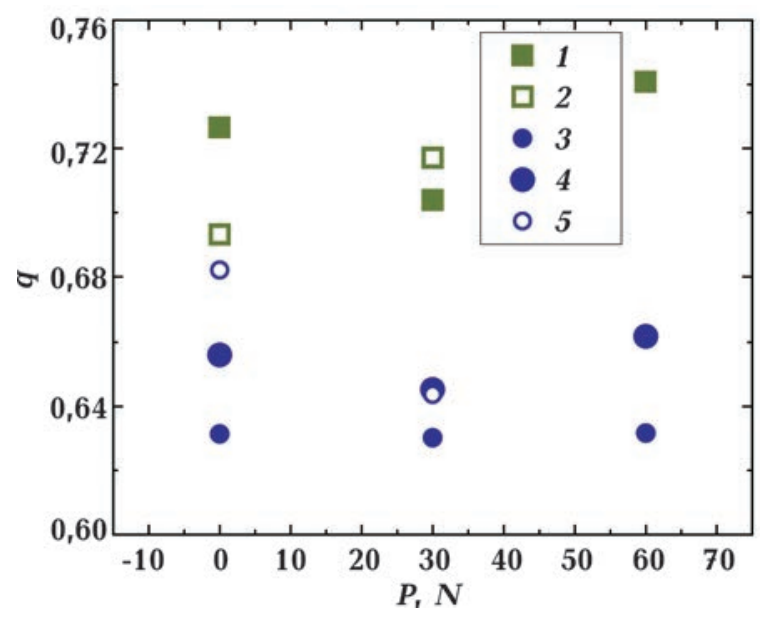

Fig. 8. Dependences of exponent of Tsallis index $q$ on the load $P$. The notations coincide with Fig. 6 . 
Concluding remarks. The results of the experiments demonstrate the complexity of dynamic behavior of the granular media formed by the ribbed grains. This complexity is similar to the complexity that is inherent in the natural media. Therefore, modeling these processes in the laboratory is of great importance for revealing statistical properties of natural critical phenomena, including earthquakes.

Experiments with shear deformation of massifs with ribbed grains have shown that the quality of the behavior of such a medium does not depend on the shape and size of the grains. The shape and size affect only the magnitudes of intergranular forces: for grains with smoother surfaces, which in experiments are pieces of crushed stone, the jumps in force are smaller compared to the medium formed by grains of regular shape - cubes. Also jumps of forces at reduction of the sizes of grains at identical forms decrease.

Based on nonintensive statistical mechanics, the analysis of the response of the granular medium to shear deformation shown that the Tsallis index for the force jump sequences

\section{References}

Agioutantis, Z., Kaklis, K., Mavigiannakis, S., Verigakis, M., Vallianatos, F., \& Saltas, V. (2016). Potential of acoustic emissions from three point bending tests as rock failure precursors. International Journal of Mining Science and Technology, 26(1), 155-160. https://doi.org/10.1016 /j.ijmst.2015.11.024.

Alexeevskaya, M., Gabrielov, A., Gvishiani, A., Gel'fand, I., \& Ya, E. (1977). Formal morphostructural zoning of mountain territories. $J_{O}$ urnal of Geophysics, 43(1), 227-233.

Behringer, R. P., Howell, D., Kondic, L., Tennakoon, S., \& Veje, C. (1999). Predictability and granular materials. Physica D, 133, 1-17. https: //doi.org/10.1016/S0167-2789(99)00094-9.

Ben-Zion, Y., \& Sammis, G.S. (2003). Characterization of fault zones. Pure and Applied Geophysics, 160, 677-715. https://doi.org/10.1007/ PL00012554. in all experiments was less than 1 . This testifies about the presence of long-range correlations in shear motion and the system dynamics is defined by the mutual influence of a large number of rare events.

Another important conclusion can be drawn from the results of experiments on shear deformation of such granular media. Under the action of small perturbations, the amplitudes of the jumps decrease for all forms of granules and all sizes, i. e., the deformation becomes smoother. Taking into account the statistical similarity of shear deformation of the granular medium and the deformation of the medium in seismically active zones, the results of the study indicate the possibility to affect the nonequilibrium structured medium in that zones via the weak loading.

The results outlined above provide understanding the seismic phenomena in seismoactive zones and can be useful for the development of seismoprotection of civil engineering structures [Kendzera et al., 2020a, b].

The work is partially supported by the projects $0118 U 000043$ and $0118 U 000044$.

Billi, A., \& Storti, F. (2004). Fractal distribution of particle size in carbonate cataclastic rocks from the core of a regional strike-slip fault zone. Tectonophysics, 384, 115-128. https://doi. org/10.1016/j.tecto.2004.03.015.

Boghosian, B.M.(1996). Thermodynamic description of the relaxation of two-dimensional turbulence using Tsallis statistics. Physical Review E, 53(5), 4754-4763. https://doi.org/10.11 03/physreve.53.4754.

Geller, D.A., Ecke, R.E., Dahmen, K.A., \& Backhaus, S. (2015). Stick-slip behavior in a continuum-granular experiment. Physical Review E, 92, 060201(R). https://doi.org/10.1103/PhysRev E.92.060201.

Howell, D., Behringer, R.P., \& Veje, C. (1999). Stress fluctuations in a 2D granular Couette experiment: A continuous transition. Physical Revi- 
ew Letters, 82(26), 5241-5244. https://doi.org/ 10.1103/PhysRevLett.82.5241.

Hayman, N.W., Ducloué, L., Foco, K.L., \& Daniels, K.E. (2011). Granular controls on periodicity of stick-slip events: kinematics and force-chains in an experimental fault. Pure and Applied Geophysics, 168, 2239-2257. https://doi. org/10.1007/s00024-011-0269-3.

Indraratna, B., Ngo, N., Rujikiatkamjorn, C., \& Vinod, J. (2014). Behavior of fresh and fouled railway ballast subjected to direct shear testing: Discrete element simulation. International Journal of Geomechanics, 14(1), 34-44. https: //doi.org/10.1061/(ASCE)GM.1943-5622.0000 264.

Keilis-Borok, V.I., \& Soloviev, A.A. (2003). Nonlinear dynamics of the lithosphere and earthquake prediction. Springer, Berlin. 337 p.

Kendzera, O.V., Mykulyak, S.V., Semenova, Yu.V., \& Skurativskyi, S.I. (2020a). Modeling of seismic response of soil layer within the framework of nonlocal model of continuous medium. Geofizicheskiy Zhurnal, 42(3), 47-58 (in Ukrainian). https://doi.org/10.24028/gzh.02033100.v42i3.2020.204700.

Kendzera, O.V., Mykulyak, S.V., Semenova, Yu.V., Skurativska, I.A., \& Skurativskyi, S.I. (2020 b). Assessment of seismic response of a soil layer with the oscillating inclusions. Geofizicheskiy Zhurnal, 42(4), 3-17. https://doi.org/10.24028/ gzh.0203-3100.v42i4.2020.210669.

Kocharyan, G.G., \& Spivak, A.A. (2003). Deformation dynamics of block rock massifs. Moscow: IKC Akademkniga, 423 p. (in Russian).

Kumar, P., Korkolis, E., Benzi, R., Denisov, D., Niemeijer, A, Schall, P., Toschi, F., \& Trampert, J. (2020). On interevent time distributions of avalanche dynamics. Scientific Reports, 10(1), 626. https://doi.org/10.1038/s41598-019-56764-6.

Lherminier, S., Planet, R., Levy dit Vehel, V., Simon, G., Vanel, L., Måløy, K.J., \& Ramos. O. (2019). Continuously sheared granular matter reproduces in detail seismicity laws. Physical
Review Letters, 122, 218501. https://doi.org/10. 1103/PhysRevLett.122.218501.

Loveless, J.P., \& Meade, B.J. (2011). Stress modulation on the San Andreas fault by interseismic fault system interactions. Geology, 39(11), 10351038. https://doi.org/10.1130/G32215.1.

McCaffrey, R. (2005). Block kinematics of the Pacific-North America plate boundary in the southwestern United States from inversion of GPS, seismological, and geologic data. Journal of Geophysical Research, 110, B07401. https:// doi.org/10.1029/2004JB003307.

Meade, B.J., \& Hager, B.H. (2005). Block models of crustal motion in southern California constrained by GPS measurements. Journal of Geophysical Research, 110, B03403. https://doi.org/ 10.1029/2004JB003209.

Meroz, Y., \& Meade, B.J. (2017). Intermittent granular dynamics at a seismogenic plate boundary. PhysicalReview Letters, 119, 138501.https:// doi.org/10.1103/PhysRevLett.119.138501.

Michas, G., Vallianatos, F., \& Sammonds, P. (2013). Non-extensivity and long-range correlations in the earthquake activity at the West Corinth rift (Greece). Nonlinear Processes in Geophysics, 20, 713-724. https://doi.org/10.5194/npg20-713-2013.

Mykulyak, S.V. (2019). The regularities of the dynamics of structured geomedia: theory, model, experiment. Extended abstract of Doctor's thesis. Kyiv. 37 p. (in Ukrainian).

Mykulyak S., Kulich V., \& Skurativskyi S. (2019a). Simulation of shear motion of angular grains massif via the discrete element method. In Z. Hu, S. Petoukhov, I. Dychka, M. He (Eds.), Advances in Computer Science for Engineering and Education. ICCSEEA 2018. Advances in Intelligent Systems and Computing (Vol. 754, pp. 74-81). Springer. https://doi.org/10.1007/9783-319-91008-6_8.

Mykulyak, S.V., Polyakovskyi, V.O., \& Skurativskyi, S.I. (2019b). Statistical properties of shear deformation of granular media and analogies with natural seismic processes. Pure and Applied Geophysics, 176, 4309-4319. https://doi. org/10.1007/s00024-019-02209-0. 
Nikolaevskiy, V.N. (1996). Geomechanics and fluid dynamics. Moscow: Nedra, 447 p. (in Russian).

Pruessner, G. (2012). Self-organized criticality. Theory, Models and Characterization. Cambridge University Press, $493 \mathrm{p}$.

Ramirez-Reyes, A., Raul, Hernandez-Montoya A., Herrera-Corral, G., \& Dominguez-Jimenez, I. (2016). Determining the entropic index q of Tsallis entropy in images through redundancy. Entropy, 18(14), 299. https://doi.org/10.3390/e180 80299.

Sadovskiy, M.A. (1989). On the meaning and sense of discreteness in geophysics: In Discrete properties of the geophysical medium (pp. 514). Moscow: Nauka (in Russian).

Sadovskiy, M.A., Bolkhovitinov, L.G., \& Pisarenko, V.F. (1982). On the property of discreteness of rocks, Izvestiya Akademii Nauk SSSR. Fizika Zemli, 12, 3-18 (in Russian).

Sadovskiy, M.A., Bolkhovitinov, L.G., \& Pisarenko, V.F. (1987). Deformation of the medium and seismic process. Moscow: Nauka, 100 p. (in Russian).

Saltas, V., Vallianatos, F., Triantis, D., \& Stavrakas, I. (2018). Complexity in laboratory seismology: From electrical and acoustic emissions to fracture. In T. Chelidze, L. Telesca, \& F. Vallianatos (Eds.), Complexity of seismic time series; measurement and Application (pp. 239-273). Amsterdam: Elsevier. https://doi.org/10.1016/ B978-0-12-813138-1.00008-0.

Tsallis, C. (2004). Nonextensive statistical mechanics: Construction and physical interpretation. In M. Gell-Mann, \& C. Tsallis (Eds.), Nonextensive Entropy: Interdisciplinary Applicati- ons (Santa Fe Institute Studies on the Sciences of Complexity)(pp. 1-53). Oxford: Oxford University Press.

Vallianatos, F., Benson, P., Meredith, P., \& Sammonds, P. (2012). Experimental evidence of a non-extensive statistical physics behavior of fracture in triaxially deformed Etna basalt using acoustic emissions. Europhysics Letters, 97(5), 58002. https://doi.org/10.1209/0295-50 75/97/58002.

Vallianatos, F., Karakostas, V., \& Papadimitriou, E. (2014). A nonextensive statistical physics view in the spatiotemporal properties of the 2003 (Mw 6.2) Lefkada, Ionian Island Greece, aftershock sequence. Pure and Applied Geophysics, 171(7), 1343-1534. https://doi.org/10.1007/s0 0024-013-0706-6.

Vallianatos, F., Michas, G., \& Papadakis, G. (2016a). A description of seismicity based on non-extensive statistical physics: A review. In Earthquakes and their impact on society (pp. 1-41). Springer. https://doi.org/10.1007/978-3-319-21 $753-6$.

Vallianatos, F., Papadakis, G., \& Michas, G. (2016b). Generalized statistical mechanics approaches to earthquakes and tectonics. Proceedings of the Royal Society A, 472, 2196. https://doi.org/ 10.1098/rspa.2016.0497.

Vallianatos, F., Michas, G., \& Papadakis, G. (2018). Non-extensive statistical seismology: An overview. In T. Chelidze, L. Telesca, \& F. Vallianatos (Eds.), Complexity of seismic time series; measurement and application (pp. 25-59). Amsterdam: Elsevier.

Zhao, D., Nezami, E.G., Hashash, Y.M.A., \& Ghaboussi, J. (2006). Three-dimensional discrete element simulation for granular materials. Engineering Computations, 23, 749-770. https:// doi.org/10.1108/02644400610689884. 


\title{
Експериментальне Аослідження зсувного Аеформування середовища, утвореного масивом ребристих гранул
}

\author{
С.В. Микуляк, В.О. Поляковський, С.І. Скуратівський, 2021 \\ Інститут геофізики ім. С. І. Субботіна НАН України, Київ, Україна
}

Підхід до вивчення сейсмоактивної зони як відкритої системи, що перебуває в стані самоорганізованої критичності, набуває усе ширшого застосування у сучасних дослідженнях. Моделі, що використовують за такого підходу, мають відображати найхарактерніші риси подібних середовищ: дискретність, нерівноважність, нелінійний та нелокальний характер взаємодій. Розглянуто середовище, яке змодельовано гранульованим масивом з гранулами ребристої форми. Аосліджено три різні масиви. В межах одного масиву усі гранули однакові, тоді як гранули з різних масивів різняться за формою (кубічна або неправильна ребриста) та характерними розмірами. Виконано ряд експериментів зсувного деформування таких гранульованих масивів з метою вивчення впливу форми та розмірів гранул на статистичні характеристики процесу. Вивчено вплив напруженого стану на деформаційні властивості вказаних середовищ. Експериментально доведено якісну подібність поведінки різних гранульованих середовищ. Отримані експериментально стрибки сил, які є реакцією гранульованого середовища на деформацію зсуву, розподілені за степеневим законом. Однак величини сил, що виникають у масивах, залежать від форми, розмірів гранул і напруженого стану в масивах. Експерименти зі зсувним деформуванням гранульованих середовищ за зовнішньої дії малих імпульсних напружень показали, що така дія зумовлює більш плавне, позбавлене різких стрибків деформування. Зовнішні збурення зміщують розподіли стрибків сил у бік менших значень, залишаючи незмінними їх показники степеня.

Аналіз експериментальних результатів з використанням неадитивної статистичної механіки підтверджує наявність далекодійних кореляцій у масиві ребристих гранул у разі його зсувного деформування.

Ключові слова: гранульоване середовище, зсувне деформування, степеневий статистичний розподіл, індекс Цалліса.

\section{Экспериментальное исследование сдвигового Аеформирования среды, образованной массивом ребристых гранул}

\author{
С.В. Микуляк, В.А. Поляковский, С.И. Скуратовский, 2021
}

Институт геофизики им. С.И. Субботина НАН Украины, Киев, Украина

Подход к изучению сейсмоактивной зоны как открытой системы, находящейся в состоянии самоорганизованной критичности, все более широко применяется в современных исследованиях. Модели, используемые в данном подходе, должны отражать наиболее характерные черты таких сред: дискретность, неравновесность, нелинейный и нелокальный характер взаимодействий. Рассмотрена среда, моделируемая гранулированным массивом с гранулами ребристой формы. Исследованы 
три разных массива. В пределах одного массива все гранулы одинаковы, тогда как гранулы из разных массивов различаются формой (кубическая или неправильная ребристая) и характерными размерами. Выполнены эксперименты сдвигового деформирования таких гранулированных массивов с целью изучения влияния формы и размеров гранул на статистические характеристики процесса. Изучено влияние напряженного состояния на деформационные свойства указанных сред. Экспериментально доказано качественное сходство поведения различных гранулированных сред. Полученные экспериментально скачки сил, которые представляют собой реакцию гранулированной среды на деформацию сдвига, распределены по степенному закону. Однако величины сил, возникающих в массивах, зависят от фрормы, размеров гранул и напряженного состояния в массивах. Эксперименты со сдвиговым деформированием гранулированных сред при внешнем воздействии малых импульсных напряжений показали, что такое действие вызывает более плавное, лишенное резких скачков деформирование. Внешние возмущения смещают распределение скачков сил в сторону меньших значений без изменения их показателей степени.

Анализ экспериментальных результатов с использованием неадлитивной статистической механики подтверждает наличие дальнедействующих корреляций в массиве ребристых гранул при его сдвиговом деформировании.

Ключевые слова: гранулированная среда, сдвиговые деформации, степенное статистическое распределение, индекс Цаллиса. 